\title{
Formic Acid
}

National Cancer Institute

\section{Source}

National Cancer Institute. Formic Acid. NCI Thesaurus. Code C83719.

A reag ent comprised of the organic chemical formic acid that cleaves proteins into peptides at the C- or $\mathrm{N}$-terminal side of an aspartate residue. 